\title{
Relationship Between Knowledge Levels Donors Age 17- 30 Years Old And Routine Blood Donation At UTD PMI Surabaya
}

\author{
Sasi Widuri * \\ Universitas Dr. Soetomo Surabaya, Indonesia \\ *sasiwiduri@ymail.com
}

\begin{abstract}
One of the causes of donors aged 17 - 30 years is less than donors over the age of 30 years and the need for blood to patients is the possibility of lack of information and level of knowledge about blood donors, so that with their ignorance about matters relating to blood donors can affect the amount of blood stock in UTD PMI in general. To determine the relationship of knowledge of blood donors aged 17 - 30 years to the routine blood donor at UTD PMI Surabaya . Researchers used a descriptive design research type that is research used to describe and present data, only to describe or analyze data but did not conclude or compile a generalization The number of samples in this study were 80 respondents. The sampling technique in this study is Simple Random Sampling. From the routine results on 80 respondents showed that there were 36 respondents (45\%) did blood donor routines and as many as 44 respondents (55\%) did not do blood donor routines at UTD PMI Surabaya and from the Chi Square test using SPSS obtained a correlation coefficient value of 0.649 because Asymp.sig value 0.649> 0.05, so based on the research hypothesis it can be concluded that if the p value $\alpha(0.05)$ then Ho is rejected and Ha is accepted, which means there is no significant relationship between the level of knowledge of donors aged 17 - 30 years with routine blood donor at UTD PMI Surabaya in this study. That there is no significant relationship between the level of knowledge of donors aged 17 - 30 years with the routine blood donor at UTD PMI Surabaya in this study. The existence of research is expected to increase the promotion of blood donors at certain age levels in order to produce good blood quality.
\end{abstract}

Keywords: Blood Donation, Blood Donor Routine, Respondents Aged 17 - 30 Years 


\section{STRADA Jurnal Ilmiah Kesehatan}

DOI: $10.30994 /$ sjik.v9i2.512

ISSN: 2252-3847 (print); 2614-350X (online)

Vol.9 No.2 November 2020 Page. 1622-1626

\section{BACKGROUND}

The availability of blood for health care is highly dependent on the willingness and awareness of the participation of the people who are willing to donate blood.

The main target for donor recruitment is to obtain a blood count according to the needs or UTD target which is focused on low-risk voluntary donors. The availability of safe and quality blood, apart from being determined by the IMLTD examination, is also greatly influenced by the right and targeted donor recruitment (Permenkes No.91 Th. 2015).

A blood donor or blood donor is someone who takes blood voluntarily to be stored in a blood bank as the availability of blood which is then used for its benefits for blood transfusions. Blood donation is common and can be done at the Central PMI Blood Transfusion Unit or the regional Blood Transfusion Unit. And every time there is also a blood donation that is held in crowded places such as in shopping centers, companies, places of worship and schools or at universities on a voluntary basis.

Basically, people's behavior is very determining the health status of an individual. Today many people do not know the importance of blood donation and even feel afraid to donate blood. Phenomenon like this causes the problem of blood availability at UTD PMI is lacking.

Knowledge or cognitive is a very important domain for the formation of a person's behavior, because behavior is based on long-lasting knowledge rather than behavior without knowledge. Good knowledge can influence and modify an individual's attitude. Knowledge is what is known by people or respondents related to health and illness or health. Meanwhile, healthy is how people or respondents think or assess things related to health.

One of the reasons for donors aged 17-30 years who is less than donors over the age of 30 years and the need for blood to patients is the possibility that there is a lack of information and level of knowledge about blood donors among donors aged 17-30 years, resulting in their ignorance of what is happening. associated with blood donors can affect the amount of blood available in UTD PMI in general. Blood donation activities that should be attended by donors aged 17-30 years do not reach the target set by UTD PMI and can also result in the quality of the blood produced being less qualified than the specified target.

\section{METHODS}

This study uses a descriptive design, namely research used to describe and present data, only to describe or analyze data but does not conclude or compile a generalization (Eka, Yulius: 2013).

The population in this study used blood donors aged 17-30 years at UTD PMI Surabaya in Januari 2019 - Mei 2019. This study is to determine the relationship between the level of knowledge of donors aged 17-30 years old with routine blood donors at UTD PMI Surabaya. The results of this study can be used as a source of information and enrich knowledge that can increase knowledge and add insight into the level of knowledge of donors aged 17-30 years of blood donation routines at UTD PMI Surabaya. The results of this study can be used as a source of information about the importance of blood donation for the community and patients, especially those who really need blood.

\section{RESULT}

It was conducted on 80 donors who met the inclusion and exclusion criteria. Bivariate data analysis is to see the relationship between two variables (Bambang: 2017). Bivariate analysis in this study was used to see the level of knowledge of blood donors aged 17-30 years of blood donation routines at UTD PMI Surabaya. 


\section{STRADA Jurnal Ilmiah Kesehatan}

DOI: $10.30994 /$ sjik.v9i2.512

ISSN: 2252-3847 (print); 2614-350X (online)

Vol.9 No.2 November 2020 Page. 1622-1626

1. Characteristics of Respondents Based on Knowledge Level

Table 4.3 Characteristics of Respondents Based on Knowledge Levels in the UTD PMI Surabaya Environment.

\begin{tabular}{cccc}
\hline No. & Category & Frequency (f) & Percentage (\%) \\
\hline 1. & Good & 54 & $67,5 \%$ \\
2. & Enough & 26 & $32,5 \%$ \\
3. & Less & 0 & 0 \\
& Total & 80 & $100 \%$
\end{tabular}

Data source : Januari 2019 - Mei 2019

Based on table 4.3, it can be seen that from 80 percent of the knowledge level of donors aged 17-30 years, 54 respondents (67.5\%) had good knowledge and 26 respondents $(32.5 \%)$ had sufficient knowledge.

2. Characteristics of Respondents Based on Blood Donation Routines

Table 4.4 Characteristics of Respondents Based on Routine Blood Donation in the UTD PMI Surabaya

\begin{tabular}{cccc}
\hline No. & Category & Frequency (f) & Percentage (\%) \\
\hline 1. & Routine Donor & 36 & $45 \%$ \\
2. & Not routine Donor & 44 & $55 \%$ \\
& Total & 80 & $100 \%$
\end{tabular}

Data source : Januari 2019 - Mei 2019

Based on table 4.4, it shows that there are 36 respondents $(45 \%)$ doing blood donation routines and 44 respondents $(55 \%)$ do not do blood donation routines at UTD PMI Surabaya.

3. Cross tabulation of the relationship between knowledge levels of donors aged 17-30 years with routine blood donations at PMI UTD Surabaya.

Table 4.5 Cross tabulation of the relationship between knowledge levels of donors aged 17-30 years with blood donation routines at UTD PMI Surabaya

\section{LEVELS OF KNOWLEDGE}

\begin{tabular}{|c|c|c|c|c|c|c|}
\hline No. & Levels & Good & & Enough & & Less \\
\hline & $\begin{array}{ll}\text { Donors } & \begin{array}{c}\text { Routine } \\
\text { blood } \\
\text { knowledge }\end{array} \\
\text { Donation }\end{array}$ & $\begin{array}{l}\text { Frequency } \\
\text { (f) }\end{array}$ & $\%$ & $\begin{array}{l}\text { Frequency } \\
\text { (f) }\end{array}$ & $\%$ & $\begin{array}{l}\text { Frequency } \\
\text { (f) }\end{array}$ \\
\hline 1. & $\begin{array}{l}\text { Routine } \\
\text { Donor }\end{array}$ & 25 & 46,3 & 12 & 46,2 & 0 \\
\hline 2. & $\begin{array}{l}\text { Not Routin Donor } \\
\text { Total } \\
\alpha \text { Chisquare }\end{array}$ & $\begin{array}{l}29 \\
54\end{array}$ & $\begin{array}{r}53,7 \\
100\end{array}$ & $\begin{array}{l}14 \\
26\end{array}$ & $\begin{array}{c}53,80 \\
100\end{array}$ & $\begin{array}{c}0 \\
80 \\
0,990\end{array}$ \\
\hline
\end{tabular}

\section{DISCUSSION}

Based on the data from the results of research in the UTD PMI Surabaya, it can be seen that blood donors who routinely carry out blood donation activities with a good level 


\section{STRADA Jurnal Ilmiah Kesehatan}

DOI: $10.30994 /$ sjik.v9i2.512

ISSN: 2252-3847 (print); 2614-350X (online)

Vol.9 No.2 November 2020 Page. 1622-1626

of knowledge are $25(46.3 \%)$ and blood donors who do not routinely carry out routine blood donations with a good knowledge level of 29 ( 53.7\%). Blood donors who routinely performed routine blood donation activities with sufficient knowledge levels were 12 (46.2\%) and blood donors who did not routinely carry out routine blood donation with sufficient knowledge levels were 14 (53.8\%).

From the statistical test, it was found that the correlation coefficient was 0.990 because the Asymp.sig value was $0.990>0.05$, it can be concluded that there was no significant relationship between the knowledge level of donors aged 17-30 years with blood donation routines at UTD PMI Surabaya in this study.

Based on the theory of knowledge is what is known by someone about something that is obtained formally or informally. Health knowledge will influence the behavior of the intermediate term outcomes of the impact of health education. Furthermore, health behavior will have an effect on increasing public health indicators as an outcome of health education (Soekidjo Notoatmodjo, 2007).

From the results of research conducted by researchers so far it can be concluded that the level of knowledge of donors aged 17-30 years has no effect on the routine of blood donors carried out by these donors, and in this case the researchers have an opinion that what is happening in the field is the possibility of donors having a moving domicile. -moved so that not only donate blood at the PMI UTD Surabaya but also at PMI UTD outside Surabaya so that it is not fully recorded at the PMI Surabaya UTD, another possibility is that the donor only follows friends, family or because as a substitute donor for their family who needs blood but does not public voluntary blood donation despite having a good level of knowledge. Another factor that affects the level of knowledge is not directly proportional to routine is the busyness of donors aged 17-30 years who are still very productive working and taking care of the household, and this factor also affects the health of the donors when donating blood because when donating blood is not allowed after tired of working. Another possibility that affects the blood donors is lack of motivation and empathy and does not consider blood donation as a life style in their life. Lack of information and education with the aim of changing people's understanding and behavior towards blood donation in schools as a curriculum that can be given starting from junior high school so that when high school high school already has a picture of blood donation. Postponing blood donation due to the problem of low hemoglobin is something that might happen in a person's routine of donating blood. Low or abnormal hemoglobin can often be caused by donors who do not adopt a healthy lifestyle, namely not maintaining their diet and quality of sleep. Besides, there are several diseases that make hemoglobin low or high in donors that are not known at that time. Donors delay donating their blood, for example when someone is fasting. The most common reasons are such as blood donation can cancel their fast, make the body weak, dizzy and others.

\section{CONCLUSION}

Based on the results of the study showed that out of 80 respondents, 62 respondents $(77.5 \%)$ were male and $18(22.5 \%)$ women were obtained:

Good knowledge $67.5 \%$ of respondents and sufficient knowledge of $32.5 \%$ of respondents. The routine blood donation routine was $45 \%$ of respondents and the blood donor routine was not routine for $55 \%$ of the respondents.

The relationship between the knowledge level of donors aged 17 - 30 years with routine blood donors at UTD PMI Surabaya from the statistical test obtained a correlation coefficient of 0.990 because the Asymp.sig value is $0.990>0.05$, it can be concluded that 


\section{STRADA Jurnal Ilmiah Kesehatan}

DOI: $10.30994 /$ sjik.v9i2.512

ISSN: 2252-3847 (print); 2614-350X (online)

Vol.9 No.2 November 2020 Page. 1622-1626

there is no significant relationship between the knowledge level of donors 17 - 30 years old with routine blood donation at UTD PMI Surabaya in this study.

The results obtained in this study indicate that the level of knowledge and routine blood donors at $17-30$ year old donors at UTD PMI Surabaya is good, based on the results of the distribution of the proportion of respondents who are the most so that the research Ho can be accepted

\section{REFERENCES}

Bambang.2017. Metode Penelitian Kuantitatif Teori dan Aplikasi Surabaya.CV. Perwira Media Nusantara (PMH).

Drs.M.NgalimPurwanto,MP.2015.Psikologi Pendidikan.PT.Remaja Rosdakarya.

Dr. Nila Kesumawati, Msi, Allen Marga Retta, M.Pd dan Novitasari, M.Pd.2017.Pengantar Statistika Penelitian.PT Raja Gravindo Persada

Dr. Budiman Chandra. 2013. Metodologi Penelitian Kesehatan, Fema Solekhah Belawati. Jakarta : EGC. 2013

Fitriana Sadikah Rachman dan dr. Robby Adity. 2013. Questions and Answers Donor Darah. Jakarta

Gunawan,Imam.2016.Pengantar Statistika Inferensial.PT.RajaGravindo Persada

Kemenkes RI.2015. Permenkes RI No.91 tahun 2015 tentang standar Pelayanan Transfusi Darah. Jakarta : Depkes RI.

Kemenkes RI 2014. PermenkesRI No. 83. 2014. Unit Transfusi Darah, Bank Darah dan Jejaring Pelayanan Transfusi Darah

Notoatmodjo, S. 2014. Promosi Kesehatan dan Perilaku Kesehatan, PT Rineka Cipta, Jakarta.

Notoatmodjo, S. 2005. Promosi Kesehatan Teori dan Aplikasi, PT Rineka Cipta, Jakarta.

Notoatmodjo, S. 2017. Pengantar Pendidikan dan Ilmu Perilaku Kesehatan. Andi Offset, Yogyakarta.

Prof. Dr. Syamsu Yusuf LN. 2018. Kesehatan Mental Perspektif Psikologi dan Agama. PT. Remaja Rosdakarya

Yulius Eka Agung Seputra, ST,Msi.2013. Statistika berbasis komputer.Jakarta : Mitra Wacana Media.

Yanto,S.T.,M.Sc.2016. Statistika Inferensi Untuk Penelitian Dengan Minitab.CV.Andi Offset 